\title{
Cell tip growth underlies injury response of marine macroalgae
}

\author{
Maki Shirae-Kurabayashi ${ }^{1 *}$, Tomoya Edzuka ${ }^{1}$, Masahiro Suzuki², and Gohta \\ Goshima $^{1,3^{*}}$ \\ ${ }^{1}$ Sugashima Marine Biological Laboratory, Graduate School of Science, Nagoya \\ University, Sugashima, 429-63, Toba 517-0004, Japan \\ ${ }^{2}$ Kobe University Research Center for Inland Seas, Iwaya, 2746, Awaji, Hyogo, 656- \\ 2401, Japan \\ ${ }^{3}$ Division of Biological Science, Graduate School of Science, Nagoya University, Furo- \\ cho, Chikusa-ku, Nagoya, Aichi 464-8602, Japan \\ ${ }^{*}$ Correspondence should be addressed to shirae@bio.nagoya-u.ac.jp or \\ goshima@bio.nagoya-u.ac.jp \\ Phone: +81 599-34-2216
}

\begin{abstract}
Regeneration is a widely observed phenomenon by which the integrity of an organism is recovered after damage. So far, studies on the molecular and cellular mechanisms of regeneration have been limited to a handful of model multicellular organisms. Here, we systematically surveyed the regeneration ability of marine macroalgae (Rhodophyta, Phaeophyceae, Chlorophyta) after thallus severing and applied live cell microscopy on them to uncover the cellular response to the damage. We observed three types of responses - budding, rhizoid formation and/or sporulation - in 25 species among 66 examined, demonstrating the high potential of regeneration of macroalgae. In contrast, callus formation, which often accompanies plant regeneration, was never observed. We monitored the cellular and nuclear dynamics during cell repair or rhizoid formation of four phylogenetically diverged Rhodophyta and Chlorophyta species (Colaconema sp., Dasya sessilis, Cladophora albida, Codium fragile). We observed tip growth of the cells near the damaged site as a common response, despite the difference in the number of nuclei and cells across species. Nuclear translocation follows tip growth, enabling overall uniform distribution of multinuclei (Dasya sessilis, Cladophora albida, Codium fragile) or central positioning of the mononucleus (Colaconema sp.). In contrast, the control of cell cycle events, such as nuclear division and septation, varied in these species. In Dasya sessilis, the division of multinuclei was synchronised, whereas it was not the case in Cladophora albida. Septation was tightly coupled with nuclear division in Colaconema and Dasya but not in others. These observations show that marine macroalgae utilise a variety of regeneration pathways, with some common features. This study also provides a novel methodology of live cell biology in macroalgae, offering a foundation for the future of this under-studied taxon.
\end{abstract}

\section{Introduction}

Regeneration is widely observed in multicellular organisms; injured tissue (e.g. the human liver and lizard's tail) or, in some cases, the whole body of an organism (e.g. planaria and moss) is eventually recovered through cell proliferation and differentiation (Duncan and Sanchez Alvarado, 2019; Murawala et al., 2012). Marine organisms often incur injuries, typically caused by storms or predators. As a result, they have certain 
48 response mechanisms to this damage. However, the regeneration process has hardly been

49 described at a cellular level for marine creatures, and the underlying mechanisms remain

50 poorly understood.

51 Marine macroalgae, or seaweeds, are important players in marine ecology (Graham et 52 al., 2008). Three types of seaweeds, namely, red (Rhodophyta), brown (Phaeophyceae), 53 and green (Chlorophyta) macroalgae, are widely distributed, particularly in coastal areas. 54 Phylogenetically, red and green algae and land plants constitute a single clade, whereas 55 brown algae are more distinct (Adl et al., 2019). Their ability to photosynthesise makes 56 them critical $\mathrm{CO}_{2}$ consumers and oxygen producers. They also serve as food sources and 57 habitats for benthic and nektonic animals, and the interaction with animals raises the risk 58 of injury. A high potential for regeneration has been described in macroalgal species. 59 When a filament of Griffithsia pacifica Kylin was severed, regrowth of the cell next to 60 the damaged cell was observed (Waaland and Cleland, 1974). In the red alga 61 Gracilariopsis chorda (Holmes) Ohmi, experimentally severed thalli were returned to the 62 ocean, and vegetative regeneration was subsequently observed (Kim et al., 2005). 63 Furthermore, in the brown alga Dictyota dichotoma (Hudson) J.V. Lamouroux, budding 64 and rhizoid formation from a severed surface has been reported in juvenile thalli (Tanaka 65 et al., 2017). In vitro regeneration assays have been also conducted, which involved artificially prepared protoplasts or the callus (Baweja et al., 2009; Mine et al., 2008). Studies show that protoplasts of the green algae Ulva (sea lettuce) and Bryopsis regenerate to form the thallus (Fujimura et al., 1989; Tatewaki and Nagata, 1970). Explants of gracilarialean red algae generate calli, which are stimulated by plant growth hormones (Gusev et al., 1987; Yokoya et al., 2004). However, the use of different assays in different studies makes it difficult to deduce whether there is a common mode of regeneration in macroalgae. Furthermore, how cells initially respond to injury remains largely unclear at both the cellular and intracellular level, as high-resolution time-lapse imaging of the cellular and intracellular components has scarcely been applied.

In this study, we conducted a systematic survey of the response to injury (which we introduced by thallus severing) of 66 locally obtained macroalgal species. Thereafter, we analysed cell growth, cell division, and nuclear dynamics. Nuclear dynamics are of particular interest in macroalgae, as many species have multiple nuclei within one cell. Our survey identified three major macroscopic responses to thallus severing, namely, bud, rhizoid, and spore formation. At the cellular level, instant cell tip growth, accompanied by nuclear translocation, was commonly observed upon injury in four red/green algal species.

\section{Materials and methods}

\section{Macroalgae collection}

Macroalgae were predominantly collected from the intertidal zone of the seashore, in front of the laboratory (Lat. 34 $29^{\circ} 8^{\prime \prime}$ N, Long. 136 $52^{\prime} 32^{\prime \prime}$ E, Fig. 1A-C) on the $25^{\text {th }}$ and $26^{\text {th }}$ of March 2020, and on the $30^{\text {th }}$ of March and $1^{\text {st }}$ of April 2021. Samples were also collected from the outside tank of the laboratory, as well as from the ropes of the floating pier (Fig. 1C-F). The macroalgae were kept in natural seawater at $15^{\circ} \mathrm{C}$ until they were severed.

\section{Identification of macroalgae}


94 Collected macroalgae were examined to determine their probable genera and/or species; 95 monographic publications and floristic studies were used to confirm the morphology and 96 identify the species (Takamine and Yamada, 1950; Yoshida, 1998). The nomenclature 97 used in this study follows Algaebase (Guiry and Guiry, 2021). DNA barcode sequencing 98 was performed for some specimens to confirm and/or correct the morphological 99 identification. The plastid $r b c \mathrm{~L}$, mitochondrial cox1, nuclear $18 \mathrm{~S}$ rDNA, and/or rDNA 100 ITS1-5.8S-ITS2 region were amplified and sequenced. Genomic DNA was extracted 101 using the DNeasy Plant Mini Kit (Qiagen, Tokyo, Japan) from field-collected specimens 102 dried by silica gel. Total DNA was used as the template for polymerase chain reactions 103 (PCR) in which the $r b c \mathrm{~L}$, cox1, 18S rDNA, and/or rDNA ITS1-5.8-ITS2 loci were 104 amplified using a KOD-ONE kit (Toyobo Co. Ltd., Osaka, Japan) and a 2720 PCR 105 Thermal Cycler (Applied Biosystems, Foster City, CA, USA). The primers used for PCR 106 amplification are shown in Table 1. The temperature cycling protocol was as follows: 2 $107 \mathrm{~min}$ at $94{ }^{\circ} \mathrm{C}$ for an initial denaturation step, 35 cycles of $15 \mathrm{~s}$ denaturation at $94{ }^{\circ} \mathrm{C}, 30 \mathrm{~s}$ 108 primer annealing at $46^{\circ} \mathrm{C}$, and 1 min extension at $68^{\circ} \mathrm{C}$, with a final 7 min extension at $10972{ }^{\circ} \mathrm{C}$, followed by a hold at $4{ }^{\circ} \mathrm{C}$. The amplified DNA fragments were purified by ethanol 110 precipitation and sequenced by eurofins genomics (Luxembourg). Reverse and direct 111 112 113 chromatograms were assembled using ClustalW software.

Table 1: Primers used for PCR amplification in this study

\begin{tabular}{|c|c|c|c|}
\hline Locus & Primer ID & Primer sequences & Reference \\
\hline \multirow{8}{*}{$r b c \mathrm{~L}$} & 981 rbcL Bryopsis-F1 & CACCTGATTACCAAGTAAAAGATAC & \\
\hline & 982 rbcL_Bryopsis-R1 & GGCTGCTAATTCAGGACTCCA & \\
\hline & 003 Dasya rbcL F1 & AAAACATTCCAAGGTCCTGCAAC & \\
\hline & 006 Dasya_rbcL_R2 & $\begin{array}{l}\text { TCTTTCCACAGGTCTAATGCTGTTTG } \\
\text { T }\end{array}$ & \\
\hline & 011_rbcL_F55 & GGYGTAATTCCATATGCWAAAATG & $\begin{array}{l}\text { Modified from } \\
\text { (Wang et al., 2019) }\end{array}$ \\
\hline & $012 \mathrm{rbcL}_{\mathrm{Rh}}{ }^{2)}$ & TYAAYTCTCARCCDTTYATACG & $\begin{array}{l}\text { Modified from } \\
\text { (Hanyuda et al., } \\
\text { 2004) }\end{array}$ \\
\hline & 013 rbcL R1150 & GCATTTGWCCACARTGAATACC & $\begin{array}{l}\text { Modified from } \\
\text { (Wang et al., 2019) }\end{array}$ \\
\hline & $014 \mathrm{rbcL}$ R1381 & ATCTTTCCATAAATCTARAGC & $\begin{array}{l}\text { Modified from } \\
\text { (Wang et al., 2019) }\end{array}$ \\
\hline \multirow{2}{*}{$\operatorname{cox} 1$} & GazF2 & CCAACCAYAAAGATATWGGTAC & (Lane et al., 2007) \\
\hline & GazR2 & GGATGACCAAARAACCAAA & (Lane et al., 2007) \\
\hline \multirow{4}{*}{$\begin{array}{l}18 \mathrm{SrD} \\
\mathrm{NA}\end{array}$} & $\begin{array}{l}\text { 001_Acro1_18SrDNA } \\
(\mathrm{G} 01)\end{array}$ & CACCTGGTTGATCCTGCCAG & $\begin{array}{l}\text { (Harper and } \\
\text { Saunders, 2002) }\end{array}$ \\
\hline & $\begin{array}{l}002 \text { Acro2 18SrDNA } \\
(\mathrm{G} 0 \overline{7})\end{array}$ & $\begin{array}{l}\text { AGCTTGATCCTTCTGCAGGTTCACCT } \\
\text { AC }\end{array}$ & $\begin{array}{l}\text { (Harper and } \\
\text { Saunders, 2002) }\end{array}$ \\
\hline & 007 Dasya 18 SrDNA 1 & ACGGTATCTGATCGTCTTCGATCC & \\
\hline & $\begin{array}{l}\text { 009_Dasya_18SrDNA_ } \\
\text { R1 }\end{array}$ & AGGTTCACCTACGGAAACCTTGT & \\
\hline \multirow{5}{*}{$\begin{array}{l}\text { rDNA } \\
\text { ITS }\end{array}$} & 015_Ulva_ITS1-U2 & GTGGGTGATCTGGAAACCCTGGAGG & $\begin{array}{l}\text { (Hanyuda et al., } \\
\text { 2018) }\end{array}$ \\
\hline & 016 Ulva ITS5-m & CCCATACCGGCACCGGTACC & $\begin{array}{l}\text { (Hanyuda et al., } \\
\text { 2018) }\end{array}$ \\
\hline & 017 Ulva ITS4-U & CGCCGYTACTARGGGAATCC & $\begin{array}{l}\text { (Hanyuda et al., } \\
2018 \text { ) }\end{array}$ \\
\hline & ITS1_Bryopsis-F & AGGAGAAGTCGTAACAAGGT & \\
\hline & ITS4 Bryopsis-R & TCCTCCGCTTATTGATATGC & \\
\hline
\end{tabular}


114

115

116

117

118

119

120

121

122

123

124

125

126

127

128

129

130

131

132

133

134

135

136

137

138

139

140

141

142

143

144

145

146

147

148

149

150

151

152

153

154

155

156

157

158

159

160

\section{Severing experiments}

The thalli of each species were washed once with filtered seawater and severed in approximately $5 \mathrm{~mm}(\times 1-5 \mathrm{~mm})$ fragments. The fragments were immersed in modified seawater (MSW), which was prepared using the following method: ocean surface water was filtered using a $0.45-\mu \mathrm{m}$ Millipore Stericup, autoclaved, and supplied with $\mathrm{GeO}_{2}$ (final concentration, $1 \mathrm{mg} / \mathrm{L}$ ) and Provasoli's enriched seawater (PES) or Daigo's IMK medium for long-term culture $\left(25^{\circ} \mathrm{C}\right.$, always expose light 1200 lux.). We checked the severed site of the algae with a stereomicroscope every day for a maximum of 21 days. For frozen sections of Gracilariopsis chorda, the served thalli were fixed with $4 \%$ paraformaldehyde in PHEM buffer (60 mM Pipes, $25 \mathrm{mM}$ Hepes, $10 \mathrm{mM}$ EGTA, $2 \mathrm{mM}$ $\mathrm{MgCl}_{2}, \mathrm{pH}$ 6.9) and frozen with OCT medium at $-80^{\circ} \mathrm{C}$ for $1 \mathrm{~h}$. Sections were prepared using CM3000 Cryostat (Lica biosystems, Wetzlar, Germany).

\section{Imaging}

Stereomicroscopic images were acquired using an ILCE-QX1 camera (Sony, Tokyo, Japan) attached to SMZ800N microscope (Nikon). A Plan $1 \times$ lens was used. Section imaging was acquired with an ILCE-QX1 camera (Sony) attached to ECLIPSE E200 (Nikon). For time-lapse microscopy, thalli were severed into $<2 \mathrm{~mm}$ pieces in the MSW and treated with Hoechst 33342 at $10 \mu \mathrm{g} / \mathrm{mL}$ (final) for DNA and cell wall staining. After 30 min incubation with the Hoechst dye, the thalli were injected into the microfluidic device which has previously been used for moss imaging (Kozgunova and Goshima, 2019). In brief, a polydimethylsiloxane (PDMS) device was attached to a glass-bottom dish (dish diameter $35 \mathrm{~mm}$; glass diameter $27 \mathrm{~mm}$; glass thickness 0.16-0.19 mm), into which severed thalli were injected by needle (Fig. S1). The height of the device was 15 $\mu \mathrm{m}$. Hoechst imaging was performed at $23{ }^{\circ} \mathrm{C}$ with a Nikon inverted microscope (Ti2) attached to a $40 \times$ lens $(0.95 \mathrm{NA})$, a 405 -nm laser, a CSU-10 spinning-disc confocal unit, and a CMOS camera (Zyla, Andor). Depending on the species under observation, sequential image acquisition time intervals varied between 10 and $30 \mathrm{~min}$. The microscopes were controlled using NIS Elements software (Nikon). The data were analysed using FIJI.

\section{Results}

\section{Budding, rhizoid formation, and sporulation are three major injury responses}

Among the macroalgal thalli collected in front of our marine laboratory (Fig. 1), we identified 54 species through visual inspection ( $26 \mathrm{red}, 21$ brown, and 7 green algae). In addition, we collected 14 species that could not be morphologically identified (Table 2). Consequently, DNA barcode sequences were determined for these unidentified species and compared with those registered in the database (Table S1). Two species died before the experiment, so we conducted serving experiments on 66 species.

Results from the 21 day-follow up of the severed sites in the algae are summarised in Fig. 2A. We observed immediate death or no specific response for 41 species, whereas the other 25 species showed three major responses: rhizoid formation (yellow arrowheads in Fig. 2B, 2E, and 2F), budding (white arrowheads in Fig. 2C-F), and sporulation (Fig. $2 \mathrm{G})$. Two or three of these responses were simultaneously observed in 11 species (Fig. $2 \mathrm{E}, \mathrm{F})$. Even though many specimens were severed in multiple locations, we did not find 
161 any site-dependent responses. There was a clear tendency in the response type for each

162 algal lineage. The majority of the brown algae showed no response (2/22 formed buds

163 and/or rhizoids) (Fig. 2A). In contrast, 47\% (16) of the red algae specimens showed

164 budding and/or rhizoid formation. Sporulation was only observed in green algae (3/10

165 showed sporulation). In all cases, buds and rhizoids were formed at the apical and basal

166 regions, respectively, indicating that the apicobasal polarity was maintained after being

167 severed (Fig. 2F). Depending on the species, buds were observed on the inner part of the

168 severed surface (Fig. 2C, S2) or at its edge (Fig. 2D). During regeneration of buds, we

169 could not observe callus-like cell masses. Rhizoid formation was observed at the basal

170 severed site (Fig. 2B, 2F). Thus, our survey revealed that macroalgae have a high

171 regeneration potential, that is limited to three patterns, budding, rhizoid formation, and

172 sporulation.

173

174

175

176

177

178

179

180

181

182

183

184

185

186

187

188

189

190

191

192

193

194

195

196

197

198

\section{Regeneration in uninuclear Colaconema sp. is characterised by cell tip growth and nuclear division, followed by septation}

We were interested in the cellular and intracellular responses to injury and studied four species in more detail, namely, Colaconema sp. (red), Dasya sessilis Yamada (red), Cladophora albida (Nees) Kützing (green), and Codium fragile (Suringar) Hariot (green). The specimens were obtained during the springtime of two successive years and were kept in the laboratory tank for $>1$ year. This meant that experiments were conducted repetitively.

Colaconema sp. is a filamentous red alga obtained from the surface of Codium (Fig. 3A). However, it grew well in seawater without Codium in the laboratory. Fig. 3B shows rhizoid formation in the basal region after severing the thallus.

To investigate the cellular and intracellular responses during rhizoid formation upon injury, we stained the nucleus with Hoechst 33342 and performed time-lapse imaging at 30 min intervals in a $15-\mu \mathrm{m}$ height microfluidic chamber (Fig. S1). The specimen was kept close to the glass surface, making higher-resolution imaging applicable (Fig. 3C, Video 1). Consistent with the DAPI staining of fixed Colaconema caespitosum (J. Agardh) Jackelman, Stegenga \& J.J. Bolton (Garbary and Zuchang, 2006), we observed a single nucleus in each cell. The cell next to the injured site started to regrow. Concomitantly, the nucleus was translocated apically, and remained in a position that was roughly central in the cell. At $540 \mathrm{~min}$, chromosomes were condensed, followed by sister chromatid separation and segregation. Septation occurred immediately after chromosome segregation (Fig. 3C, arrowhead). Fig. 3D schematically describes the injury response.

\section{Regeneration of multinuclear Dasya sessilis starts with cell death, followed by neighbour growth, synchronous nuclear division, and septation}

The red alga $D$. sessilis develops a cylindrical erect axis, with branches gradually becoming shorter towards the top. Each branch is covered with dense adventitious pseudo-laterals composed of multinucleated cells (Fig. 4A). Upon severing of the thallus, new cells were observed in the apical and basal regions and were morphologically indistinguishable. However, only the cells on the apical side formed branches on day 5, indicating that buds and rhizoids formed in the apical and basal regions, respectively (Fig. 4B).

To investigate the cellular and intracellular responses to severing, particularly regarding how rhizoids are formed, we stained the nuclei with Hoechst 33342 and 
208 performed time-lapse imaging at 30 min intervals in the microfluidic chamber (Fig. 4C,

209 Video 2). In comparison to the clarity obtained with cell wall staining, nuclear staining 210 was not very clear in D. sessilis. Nevertheless, consistent with a previous description 211 (Graham et al., 2008), we observed multiple nuclei in each cell (Fig. 4C, arrows). The 212 severed cell immediately died, suggesting that the cell repair mechanisms observed in 213 some coenocytes (Mine et al., 2008) do not operate in D. sessilis. However, the cell 214 adjacent to the injured site started to show tip growth, and concomitantly the nuclei moved 215 in an apical direction (Fig. 4C). At 1590 and $2220 \mathrm{~min}$, the chromosomes of all four nuclei 216 in the focal plane were condensed (Fig. 4C). We were able to trace the entire process in 217 three cells, all of which showed synchronous mitotic chromosome condensation. Thus, 218 mitosis is likely to be synchronised in D. sessilis. The precise timing of chromosome 219 segregation was not visible at our time resolution; nevertheless, we were able to determine 220 that it occurred within $30 \mathrm{~min}$ after mitotic entry, based on the disappearance of 221 condensed chromosomes. Septation occurred within $1 \mathrm{~h}$ of chromosome segregation (Fig. $2224 \mathrm{C}$, blue arrows). Despite the multiple nuclear segregation events that occurred at one 223 time, the septum was formed only at one site, preserving the multinuclear state of the cell after septation (Fig. 4D).

\section{Regeneration of multinucleate Cladophora albida is characterised by simultaneous tip growth of apical and subapical cells, followed by partially synchronous multinuclear division}

The green algae Cladophora albida belongs to the family Cladophoraceae. As typical to this family, it develops filamentous, monosiphonous thalli with branches composed of multinucleate cells. Upon severing, all three major responses were observed (Figs. 2E sporulation - and 5A - bud and rhizoid formation). As previously seen in Cl. glomerata (Linnaeus) Kützing using DAPI staining (Zulkifly et al., 2013), we observed multiple nuclei in a cell (Fig. 5B-D). The cell next to the severed site started to regrow rapidly (1. $9 \pm 0.5 \mu \mathrm{m} / \mathrm{min}, \mathrm{n}=14)$. In addition, adjacent cells further away from the injured site regrew at a slightly slower rate $(0.9 \pm 0.3 \mu \mathrm{m} / \mathrm{min}, \mathrm{n}=9)$, which was neither observed in Colaconema sp. nor D. sessilis. In most cases, the cells next to the severed site elongated without nuclear division, and the vacuoles developed rapidly, occupying the cytoplasm in the elongated cells (Fig. 5B, Video 3). In two cases, however, we observed many nuclear division events in the elongated cells (Fig. 5C, coloured arrows, Video 4). We found that not all nuclear divisions were entirely synchronised. While synchronous nuclear divisions were observed for some nuclei, others divided at different time points. This is different from that observed in D. sessilis, in which all nuclear divisions within a cell were synchronised. Septation occurred infrequently (Fig. 5C, white arrowheads).

\section{Regeneration of Codium fragile involves cell repair and new tip growth, followed by nuclear translocation without division}

The green algae Codium fragile belongs to family Codiaceae, In C. fragile, the thick branches are composed of closely packed utricles, which consist of small cylindrical clubshaped structures (Fig. 6A, top right). The structure is characterised by an ellipsoidal portion and two associated medullary filaments (Fig. 6A, bottom left). The cytoplasm is continuous, with only an incomplete septum between the filaments and the ellipsoidal portion (Fig. 6A, blue arrow) (Nanba et al., 2002; Nanba et al., 2000). The structure could be maintained in a petri dish with MSW for less than two weeks; thereafter, the ellipsoidal 
255 portion lost the plastids while medullary filaments started to grow (Fig. 6A, bottom right).

256 The filament kept growing for more than a year in the petri dish.

We conducted a severing experiment on isolated filamentous thalli. Upon severing of a filament at two sites, we observed a unique response, in which the severed site was immediately ( $<30 \mathrm{~min}$ ) repaired or enclosed and growth was observed at both ends (Fig. 6B). Hoechst staining confirmed the multinucleate nature of the filaments (Fig. 6C, D, Video 5). After $20 \mathrm{~h}$, protrusion and subsequent tip growth were observed adjacent to the cut site (Fig. 6C, orange arrow). In contrast to $\mathrm{D}$. sessilis and $\mathrm{Cl}$. albida, mitotic chromosome segregation or chromatid segregation was not observed in the severed area. Interphase nuclei were translocated into the newly formed protrusions without mitosis (1490-1690 $\mathrm{min})$. Once the protrusion grew to a certain length, incomplete septation was observed, through which large organelles such as the nucleus could no longer pass (Fig. $6 \mathrm{C}$, blue arrow).

\section{Discussion}

\section{Macroalgal response to injury}

To systematically study the injury response of macroalgae, we conducted a single thallus severing assay for 66 macroalgal species and observed the response at the macroscopic and, for some species, cellular and intercellular levels. Three responses were observed, namely, budding, rhizoid formation, and sporulation. The dominant response depended on the species. Nevertheless, all these responses would be reasonable for macroalgal survival in the natural environment. Rhizoid formation, which often occurred within 3 days, would allow the severed thallus to quickly re-attach to the substrate, while budding efficiently restored the cell types that had been lost by severing. Sporulation occurred within 1 day (Cl. albida) or 14-21 days (Ulva linza Linnaeus), enabling the transportation and development of a new thallus. It should be noted, however, that the 'negative' results observed in the assay (either death or no specific response) in 41 different samples were not conclusive; we hypothesize that the response-ability might be endowed to every species but could not be revealed in our specific experimental conditions (e.g. lack of water flow and the irregular lighting). Furthermore, although sporulation was observed only in green algae in this study, the same response has been reported upon wounding or heat stress in Rhodophyta (Suda and Mikami, 2020), and this response may be dependent on the age of the thalli. Besides, rhizoid and bud formation have been reported to occur in the juveniles of some Phaeophyceae species, such as Sargassum and Dictyota (Tanaka et al., 2017; Uji et al., 2015). However, we failed to observe the response for most Phaeophyceae, including Sargassum. Thus, the frequency of regenerating species may be underestimated, and this study reinforces the idea that macroalgae have a high regeneration rate (Baweja et al., 2009; Huang and Fujita, 1997).

An unexpected finding in this study was that we were unable to observe the formation of callus, the cell mass containing undifferentiated cells. The buds formed at the severed site in Rhodophyta Gelidium elegans Kützing and Gr. chorda were organised in form, thus suggesting the absence of callus formation. Callus formation is the best-known wound-healing response of land plants and has also been reported in many macroalgal species (Baweja et al., 2009; Ikeuchi et al., 2016; Perez-Garcia and Moreno-Risueno, 2018). However, many studies on callus formation in macroalgae are based on in vitro 301 tissue cultures, often supplied with extrinsic compounds such as high doses of plant 
302 hormones (Baweja et al., 2009). Our observation of the cellular response of four

303 macroalgal species also supports the notion that the callus is not a general intermediate 304 during macroalgal regeneration after injury.

\section{Injury response at the cellular and intracellular level}

To the best of our knowledge, this study represents the first report of the nuclear dynamics of macroalgae, based on live cell imaging. Generally, fluorescence imaging is challenging for photosynthetic organisms because of the high autofluorescence derived from plastids. Macroalgae are not an exception, and we detected very high signals when the samples were imaged with $560 \mathrm{~nm}$ and $640 \mathrm{~nm}$ lasers, and to a lesser extent, with a $488 \mathrm{~nm}$ laser; this last laser is routinely used for GFP imaging. However, autofluorescence was negligible when cells were illuminated with a $405 \mathrm{~nm}$ laser, allowing nuclear staining by Hoechst 33342, which is permeable to many, if not all, cell types. Hoechst staining also stained the cell wall, serving as a clear indicator of the cell growth direction and the timing of septation. One caveat of Hoechst imaging is that the low-wavelength laser confers toxicity to cells. In our case, this was minimised by lowering the laser power and exposure time as much as possible and allowing sufficient off-time between image acquisitions. The use of microfluidic devices also made a critical contribution to live imaging, as the nuclear image could be obtained by single focal plane imaging (i.e. minimal laser exposure). We believe that the intact cellular state was maintained during our imaging, as evidenced by the occurrence of mitotic cell division (in three species) and nuclear translocation (in Codium). We propose that the current method can be applicable to the nuclear imaging of many macroalgal species.

In three species, the injured cells were abandoned irrespective of the number of intact nuclei retained within them, and the neighbouring cells started the reaction. The injury might be recognised by the neighbouring cells, the cytoplasm of which might be connected through pit plugs, a structure formed between adjoining cells during an incomplete septation in cytokinesis in red algae (Pueschel and Cole, 1982). Codium was distinct in that it quickly repaired the injured site, perhaps by membrane closure. The function of the incomplete septum ('broken wall') in this process remains unclear. A similar response was observed for Bryopsis, which belongs to the same order as Codium. A highly viscous cytoplasm might underlie this quick repair of large injuries. The next step was tip growth of the injured or neighbouring cells. Nuclear migration then followed to maintain the relative position of the nucleus in a cell. This behaviour is similar to what has been observed in the multinucleated xanthophycean algae Vaucheria, where the nuclei are moved towards the branches that have been exposed to blue light (Takahashi et al., 2001). The tip growth and nuclear translocation were commonly observed in all four species. In contrast, there appeared to be a substantial variation in cell cycle control. While Dasya cells underwent synchronous nuclear division, this was not the case in Cladophora. In Cladophora, the nuclei that were closely located to each other tended to undergo synchronous division, whereas those in other areas did not, despite sharing the same cytoplasm. Single-nucleated Colaconema was similar to Dasya, in the sense that tip growth and nuclear motility were coupled. Codium, however, is extremely different, in that mitosis has been scarcely observed during regeneration. In our imaging attempts $(>$ 10 ), we observed only one nuclear division among $>100$ nuclei. The injury response of Codium may represent cellular wound healing, which does not affect cell cycle control. Finally, we found that the formation of the septum, including the incomplete septum in 
Codium, was a variable process. Interestingly, in Rhodophyta Colaconema and Dasya, this was tightly coupled with nuclear division and formed immediately after nuclear segregation. In contrast, septum formation was loosely coupled with nuclear division in (multinucleated) Chlorophyta, Cladophola, and Codium. In the multinucleated fungus Aspergillus nidulans $\mathrm{G}$ Winter, septation occurs once the tip has grown to a certain length (Wolkow et al., 1996). However, this does not appear to hold true for Cladophora, as we could not infer whether and when septation takes place based on cell length (Fig. 5B, C). The regulation of septum formation is an interesting topic for future research.

\section{Acknowledgments}

We thank Noiri Oguri, Daisuke Iijima, and Gakuho Kurita (Nagoya University) for assistance with macroalgae collection and severing, Masashi Fukuoka (NU-MBL) for macroalgae maintenance, Takeaki Hanyuda and Hiroshi Kawai (Kobe University, Japan) for instructions on basic seaweed handling, Yukimasa Yamagishi (Fukuyama University), and Toyoki Iwao (Toba City Fisheries Research Center) for helping with species identification. This work was supported by a JSPS KAKENHI grant (17H06471 to G.G., $21 \mathrm{H} 04162$ to M.S-K., and 20K06797 to M.S.). The authors declare no conflicts of interest.

\section{References}

Adl, S.M., D. Bass, C.E. Lane, J. Lukes, C.L. Schoch, A. Smirnov, S. Agatha, C. Berney, M.W. Brown, F. Burki, P. Cardenas, I. Cepicka, L. Chistyakova, J. Del Campo, M. Dunthorn, B. Edvardsen, Y. Eglit, L. Guillou, V. Hampl, A.A. Heiss, M. Hoppenrath, T.Y. James, A. Karnkowska, S. Karpov, E. Kim, M. Kolisko, A. Kudryavtsev, D.J.G. Lahr, E. Lara, L. Le Gall, D.H. Lynn, D.G. Mann, R. Massana, E.A.D. Mitchell, C. Morrow, J.S. Park, J.W. Pawlowski, M.J. Powell, D.J. Richter, S. Rueckert, L. Shadwick, S. Shimano, F.W. Spiegel, G. Torruella, N. Youssef, V. Zlatogursky, and Q. Zhang. 2019. Revisions to the Classification, Nomenclature, and Diversity of Eukaryotes. J Eukaryot Microbiol. 66:4-119.

Baweja, P., D. Sahoo, P. García-Jiménez, and R.R. Robaina. 2009. Review: Seaweed tissue culture as applied to biotechnology: Problems, achievements and prospects. Phycological Research. 57:45-58.

Duncan, E.M., and A. Sanchez Alvarado. 2019. Regulation of Genomic Output and (Pluri)potency in Regeneration. Annu Rev Genet. 53:327-346.

Fujimura, T., T. Kawai, M. Shiga, T. Kajiwara, and A. Hatanaka. 1989. Regeneration of protoplasts into complete thalli in the marine green alga Ulva pertusa. Nippon Suisan Gakkaishi. 55:1353-1359.

Garbary, D.J., and P. Zuchang. 2006. Mitochondrial Dynamics in Red Algae. 3. Filament Apices in Colaconema caespitosum (Acrochaetiales) and Antithamnion cruciatum (Ceramiales). Algae. 21:323-332.

Graham, J.E., L.W. Wilcox, and L.E. Graham. 2008. Algae (2nd Edition). Benjamin Cummings.

Guiry, M.D., and G.M. Guiry. 2021. AlgaeBase. World-wide electronic publication, National University of Ireland, Galway.

Gusev, M.V., A.H. Tambiev, N.N. Kirikova, N.N. Shelyastina, and R.R. Aslanyan. 1987. Callus formation in seven species of agarophyte marine algae. Marine Biology. 95:593-597.

Hanyuda, T., G.I. Hansen, and H. Kawai. 2018. Genetic identification of macroalgal species on Japanese tsunami marine debris and genetic comparisons with their wild populations. Mar Pollut Bull. 132:74-81. 
399

400

401

402

403

404

405

406

407

408

409

410

411

412

413

414

415

416

417

418

419

420

421

422

423

424

425

426

427

428

429

430

431

432

433

434

435

436

437

438

439

440

441

442

443

444

445

446

447

448

449

450

451

452

Hanyuda, T., Y. Suzawa, S. Arai, K. Ueda, and S. Kumano. 2004. Phylogeny and taxonomy of freshwater Bangia (Bangiales, Rhodophyta) in Japan. Journal of Japanese Botany:262-268.

Harper, J.T., and G.W. Saunders. 2002. MOLECULAR SYSTEMATICS OF THE FLORIDEOPHYCEAE (RHODOPHYTA) USING NUCLEAR LARGE AND SMALL SUBUNIT rDNA SEQUENCE DATA. Journal of Phycology. 37:10731082.

Huang, W., and Y. Fujita. 1997. Callus induction and thallus regeneration in some species of red algae. Phycological Research. 45:105-111.

Ikeuchi, M., Y. Ogawa, A. Iwase, and K. Sugimoto. 2016. Plant regeneration: cellular origins and molecular mechanisms. Development. 143:1442-1451.

Kim, J.H., S.D. Lee, S.J. Choi, I.K. Chung, and J.A. Shin. 2005. Cultivation of Gracilaria chorda (Gracilariales, Rhodophyta) by Vegetative Regeneration. Algae. 20:141150.

Kozgunova, E., and G. Goshima. 2019. A versatile microfluidic device for highly inclined thin illumination microscopy in the moss Physcomitrella patens. Sci Rep. 9:15182.

Lane, C.E., S.C. Lindstrom, and G.W. Saunders. 2007. A molecular assessment of northeast Pacific Alaria species (Laminariales, Phaeophyceae) with reference to the utility of DNA barcoding. Mol Phylogenet Evol. 44:634-648.

Mine, I., D. Menzel, and K. Okuda. 2008. Morphogenesis in giant-celled algae. Int Rev Cell Mol Biol. 266:37-83.

Murawala, P., E.M. Tanaka, and J.D. Currie. 2012. Regeneration: the ultimate example of wound healing. Semin Cell Dev Biol. 23:954-962.

Nanba, N., R. Kado, H. Ogawa, and Y. Komuro. 2002. Formation and growth of filamentous thalli from isolated utricles with medullary filaments of Codium fragile spongy thalli. Aquatic Botany. 73:255-264.

Nanba, N., R. Kado, H. Ogawa, and K. Toyama. 2000. Assays for Evaluating Seaweed Attachment Using Isolated Utricles of Codium fragile(Codiales, Chlorophyceae). I. Selection of Suitable Utricles for Assays. Sessile Organisms. 17:23-30.

Perez-Garcia, P., and M.A. Moreno-Risueno. 2018. Stem cells and plant regeneration. Dev Biol. 442:3-12.

Pueschel, C.M., and K.M. Cole. 1982. Rhodophycean Pit Plugs: An Ultrastructural Survey with Taxonomic Implications. American Journal of Botany. 69.

Suda, M., and K. Mikami. 2020. Reproductive Responses to Wounding and Heat Stress in Gametophytic Thalli of the Red Alga Pyropia yezoensis. Frontiers in Marine Science. 7.

Takahashi, F., T. Hishinuma, and H. Kataoka. 2001. Blue light-induced branching in Vaucheria. Requirement of nuclear accumulation in the irradiated region. Plant Cell Physiol. 42:274-285.

Takamine, N., and S. Yamada. 1950. A list of marine algae of Sugashima, Ise Bay. Shokubutsugaku Zasshi. 63:265-269.

Tanaka, A., Y. Hoshino, C. Nagasato, and T. Motomura. 2017. Branch regeneration induced by sever damage in the brown alga Dictyota dichotoma (dictyotales, phaeophyceae). Protoplasma. 254:1341-1351.

Tatewaki, M., and K. Nagata. 1970. Surviving Protoplasts in Vitro and Their Development in Bryopsis. Journal of Phycology. 6:401-403.

Uji, T., D. Nanaumi, C. Kawagoe, N. Saga, and K. Miyashita. 2015. Factors influencing the induction of adventitious bud and callus in the brown alga Sargassum horneri (Turner) C. Agardh. Journal of Applied Phycology. 28:2435-2443.

Waaland, S.D., and R.E. Cleland. 1974. Cell repair through cell fusion in the red alga Griffithsia pacifica. Protoplasma. 79:185-196.

Wang, H.W., S. Kawaguchi, T. Horiguchi, and M. Masuda. 2019. Reinstatement of Grateloupia catenata (Rhodophyta, Halymeniaceae) on the basis of morphology and rbcL sequences. Phycologia. 39:228-237. 
Wolkow, T.D., S.D. Harris, and J.E. Hamer. 1996. Cytokinesis in Aspergillus nidulans is controlled by cell size, nuclear positioning and mitosis. J Cell Sci. 109 ( Pt 8):2179-2188.

Yokoya, N.S., J.A. West, and A.E. Luchi. 2004. Effects of plant growth regulators on callus formation, growth and regeneration in axenic tissue cultures of Gracilaria tenuistipitata and Gracilaria perplexa (Gracilariales, Rhodophyta). Phycological Research. 52:244-254.

Yoshida, T. 1998. Marine algae of Japan. Uchida Rokakuho Publishing Co., Ltd. [in Japanese].

Zulkifly, S.B., J.M. Graham, E.B. Young, R.J. Mayer, M.J. Piotrowski, I. Smith, and L.E. Graham. 2013. The Genus Cladophora Kutzing (Ulvophyceae) as a Globally Distributed Ecological Engineer. J Phycol. 49:1-17.

\section{Video legends}

Video 1: Tip growth, nuclear division, and septation in Colaconema sp.

Time-lapse imaging of Hoechst 33342 using spinning-disc confocal microscopy. Arrow indicates condensed chromosomes in mitosis.

Video 2. Tip growth, synchronised multinuclear division, and septation in Dasya sessilis.

Time-lapse imaging of Hoechst 33342 using spinning-disc confocal microscopy. Arrows indicate condensed chromosomes in mitosis.

Video 3. Tip growth without nuclear division or septation in Cladosphora albida.

Time-lapse imaging of Hoechst 33342 using spinning-disc confocal microscopy.

Video 4. Tip growth, unsynchronised multinuclear division, and septation in Cladosphora albida.

Time-lapse imaging of Hoechst 33342 using spinning-disc confocal microscopy. Arrows indicate condensed chromosomes in mitosis.

\section{Video 5. Tip growth, nuclear migration and incomplete septum formation in Codium} fragile.

Time-lapse imaging of Hoechst 33342 using spinning-disc confocal microscopy.

\section{Tables}

Table 1: Primers used for PCR amplification in this study.

Table 2. Summary of the response to thallus severing. Grey: untested.

Table S1: DNA barcode sequences of several macroalgal species 
Table 2. Summary of the response to thallus severing. Grey: untested.

\begin{tabular}{|c|c|c|c|c|c|c|c|c|c|c|c|c|c|c|c|c|c|c|c|c|c|c|}
\hline 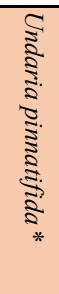 & 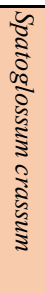 & 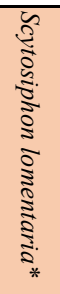 & 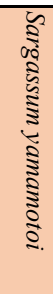 & 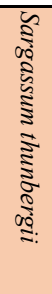 & 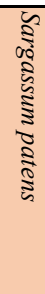 & 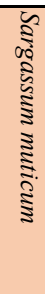 & 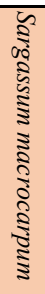 & 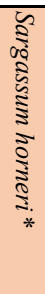 & 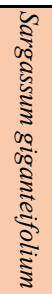 & 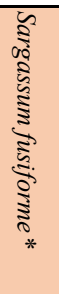 & 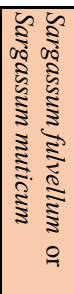 & 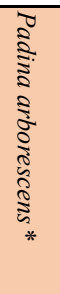 & 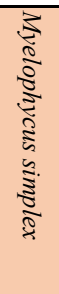 & 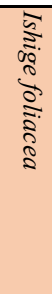 & 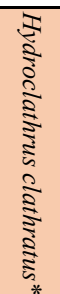 & 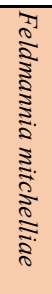 & 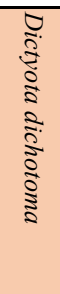 & 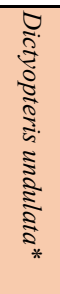 & 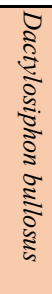 & 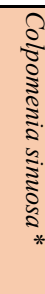 & 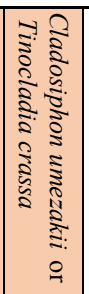 & 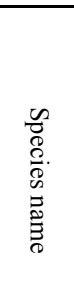 \\
\hline & & & & & & & & & & & & & & & & $<$ & & & & & & $\underset{\Xi}{\Xi}$ \\
\hline & & & & & & & & & & & & & $<$ & & & $<$ & & & & & & $\begin{array}{l}0 \\
0 \\
0.0\end{array}$ \\
\hline & & & & & & & & & & & & & & & & & & & & & & $\frac{1}{0}$ \\
\hline
\end{tabular}

\begin{tabular}{|c|c|c|c|c|c|c|c|c|c|c|c|c|c|c|c|c|c|c|}
\hline 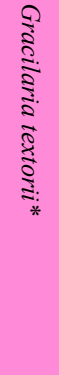 & 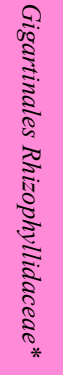 & 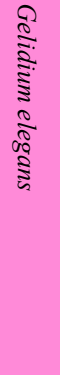 & 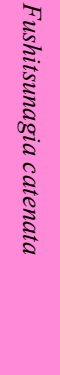 & 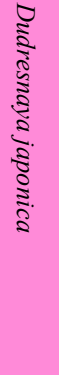 & 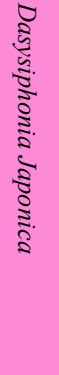 & 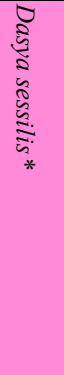 & 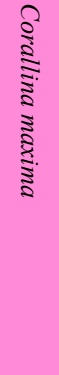 & 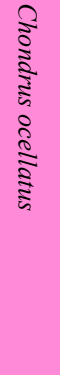 & 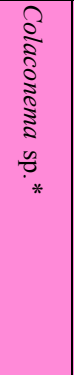 & 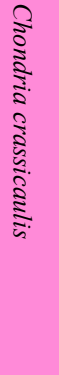 & 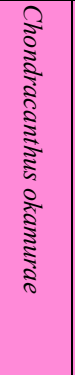 & 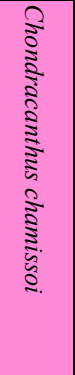 & 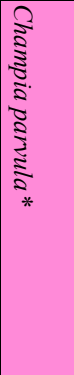 & 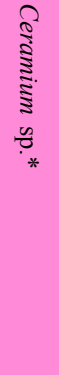 & 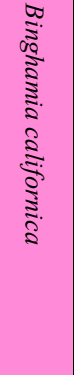 & 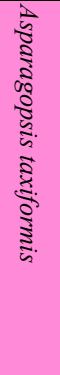 & 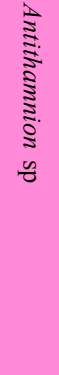 & 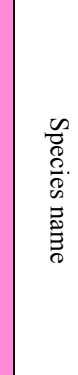 \\
\hline & & $<$ & $<$ & & & $<$ & & & $<$ & & & $<$ & & $<$ & & $<$ & & $\underset{\Xi}{ \pm}$ \\
\hline & & & & & & $<$ & $<$ & & $<$ & & & & & $<$ & & $<$ & & 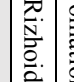 \\
\hline & & & & & & & & & & & & & & & & & & 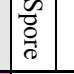 \\
\hline 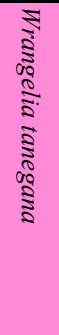 & 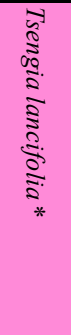 & 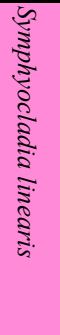 & 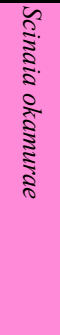 & 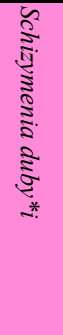 & 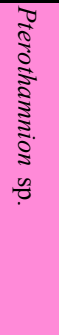 & 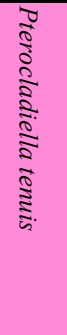 & 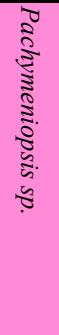 & 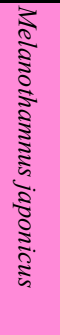 & 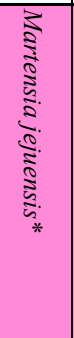 & 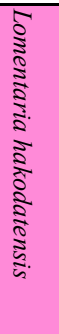 & 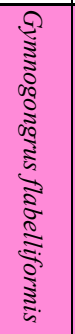 & 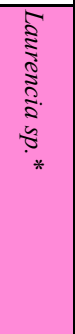 & 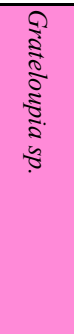 & 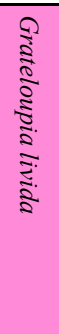 & 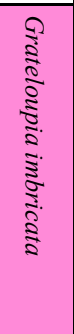 & 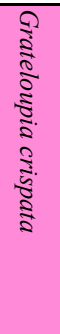 & 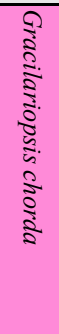 & 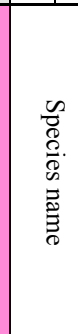 \\
\hline & & $<$ & & & $<$ & $<$ & & $<$ & $<$ & & & & & $<$ & & & $<$ & $\underset{\Xi}{ \pm}$ \\
\hline$<$ & & $<$ & & & & & & $<$ & & & & & & & & & & 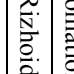 \\
\hline & & & & & & & & & & & & & & & & & & $\begin{array}{l}0 \\
0 \\
0 \\
0\end{array}$ \\
\hline
\end{tabular}

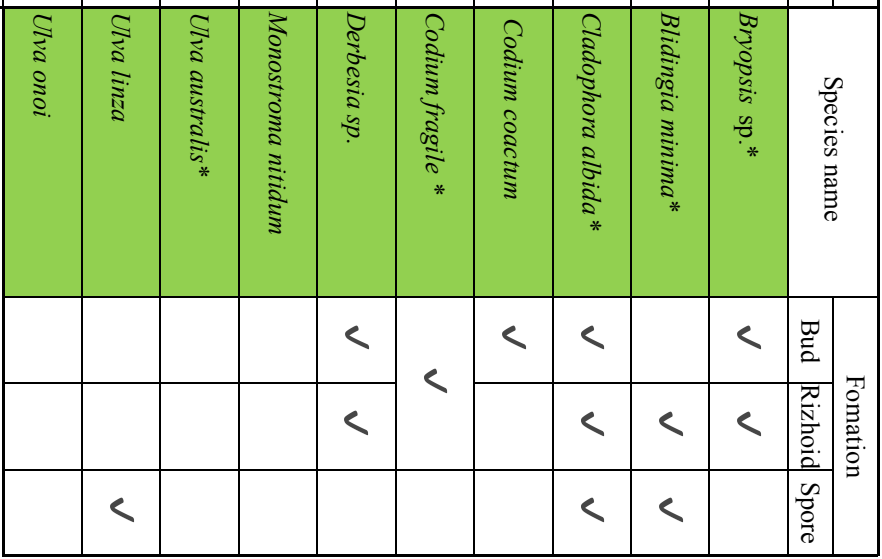



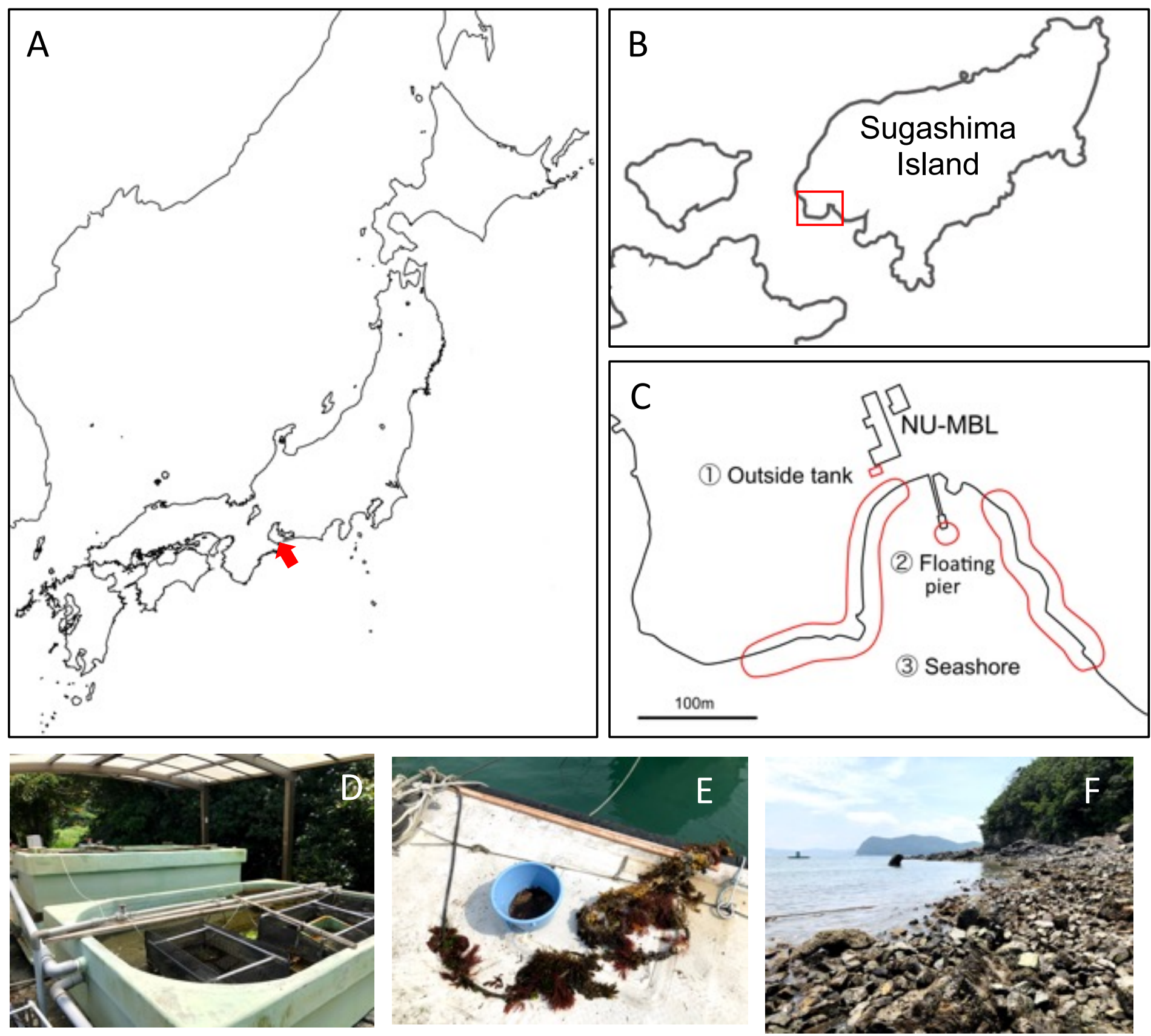

Figure 1. Macroalgae collection sites.

(A-C) Location of the Sugashima Marine Biological Laboratory (NU-MBL) and sample collection sites (indicated by red marks). (D-F) The three sites of macroalgae collection. Outdoor tank at NU-MBL which has a continuous flow of unfiltered seawater (D), the underwater rope at the pier was a source of macroalgae (E), and the intertidal zone in front of the NU-MBL (F). 
bioRxiv preprint doi: https://doi.org/10.1101/2021.08 28.458046; this version posted August 29, 2021. The copyright holder for this preprint (which was not certified by peer review) is the author/funder, who has granted bioRxiv a license to display the preprint in perpetuity. It is made available under aCC-BY-NC 4.0 International license.

A

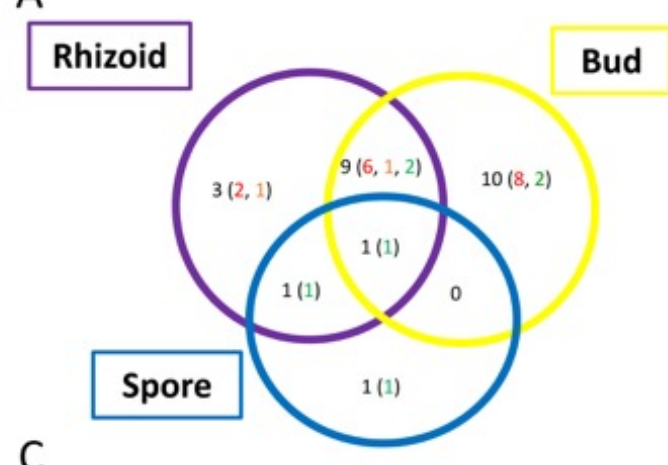

B

C

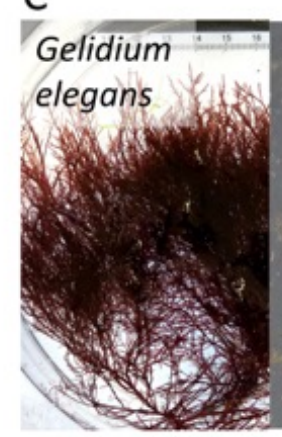

$\mathrm{E}$

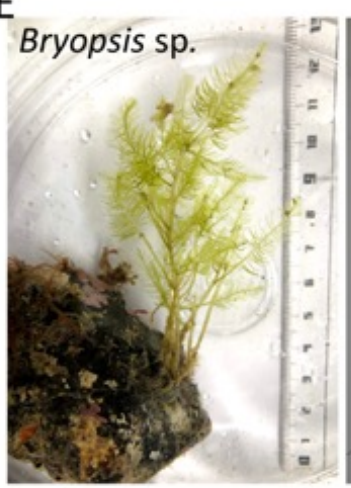

G

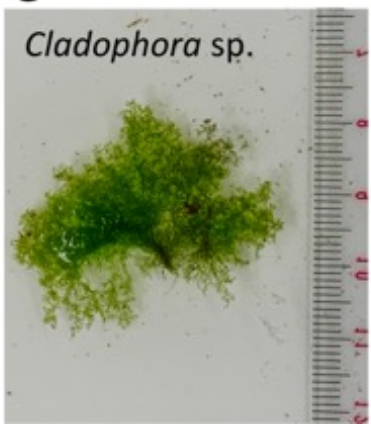

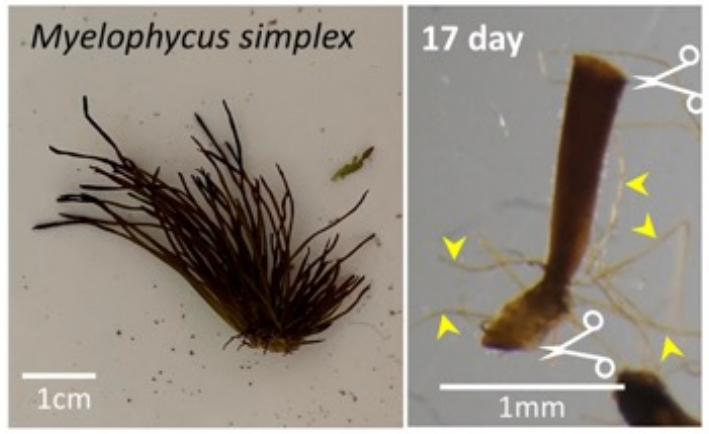

D

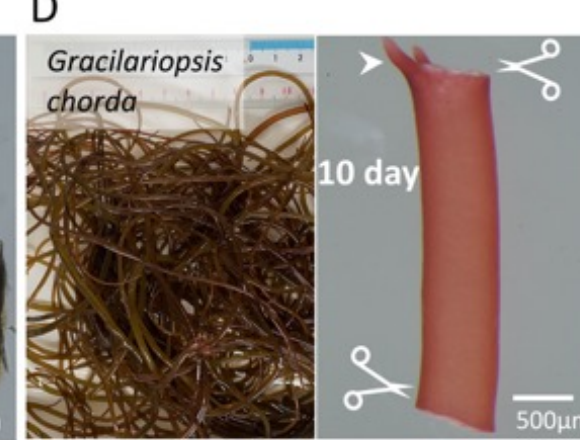

100

$\mathrm{F}$

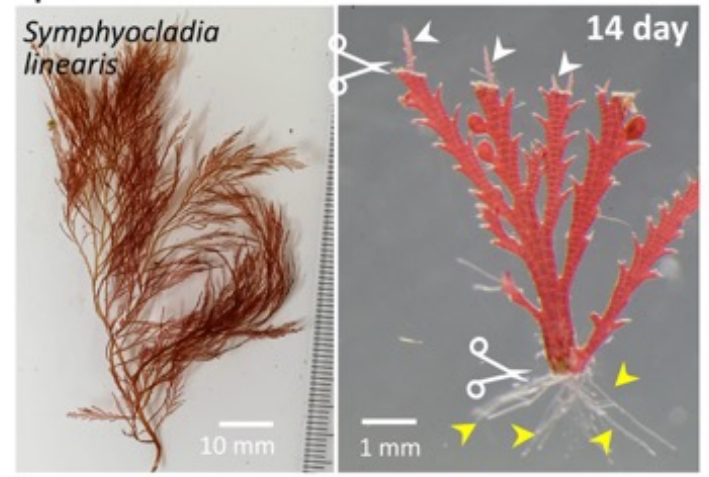

$1 \mathrm{~mm}$
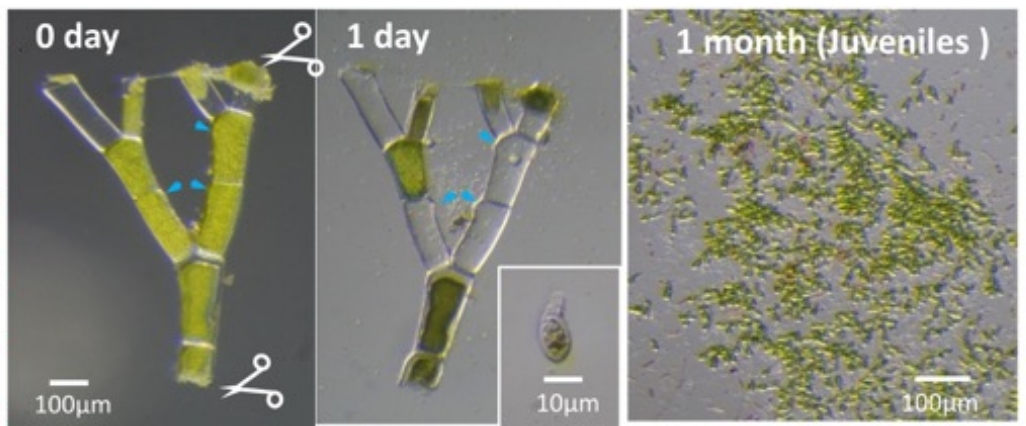

Figure 2. Budding, rhizoid formation, and sporulation are the major responses to injury.

(A) Number of macroalgal species that showed the indicated response. The numbers of red, brown, and green algae are indicated by their colours. (B) Rhizoid formation at the basal cut site in Myelophycus simplex. (C) Budding at the cut site of Gelidium elegans. The rightmost panel is a section image of the blue dotted line in the second panel. Buds appeared in the inner part of the cut surface. (D) Buds appeared at the edge of the cut surface in Gracilariopsis chorda. (E) Bud and rhizoid formation after cutting of Bryopsis sp. (F) Bud and rhizoid formation after cutting of Symphyocladia linearis. (G) Sporulation in Cladophora albida. Within $24 \mathrm{~h}$ after injury, spores were formed and released from the thalli. White arrowhead, bud; yellow arrowhead, rhizoid; blue arrowhead, pore through which spores are released. 

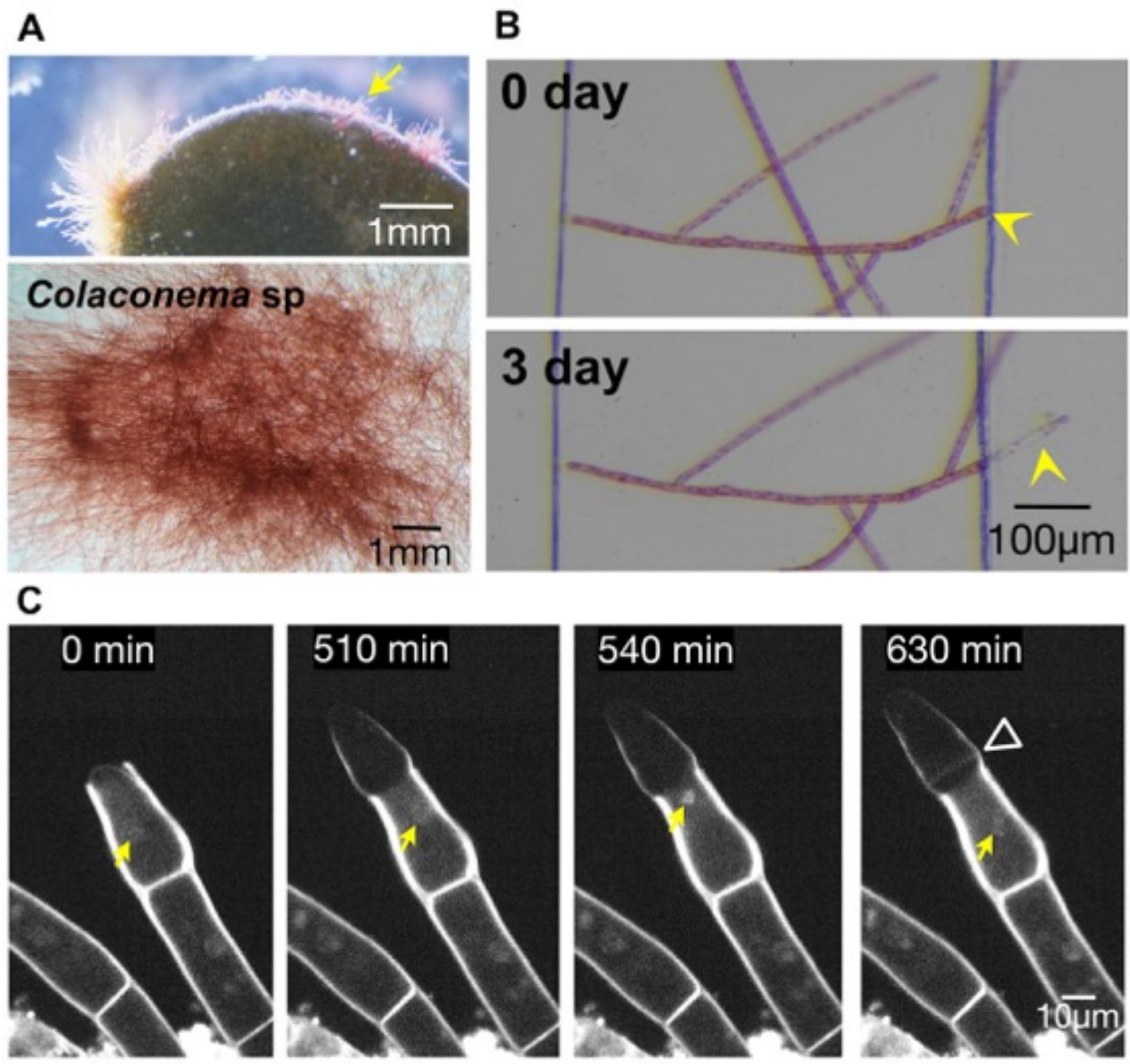

D

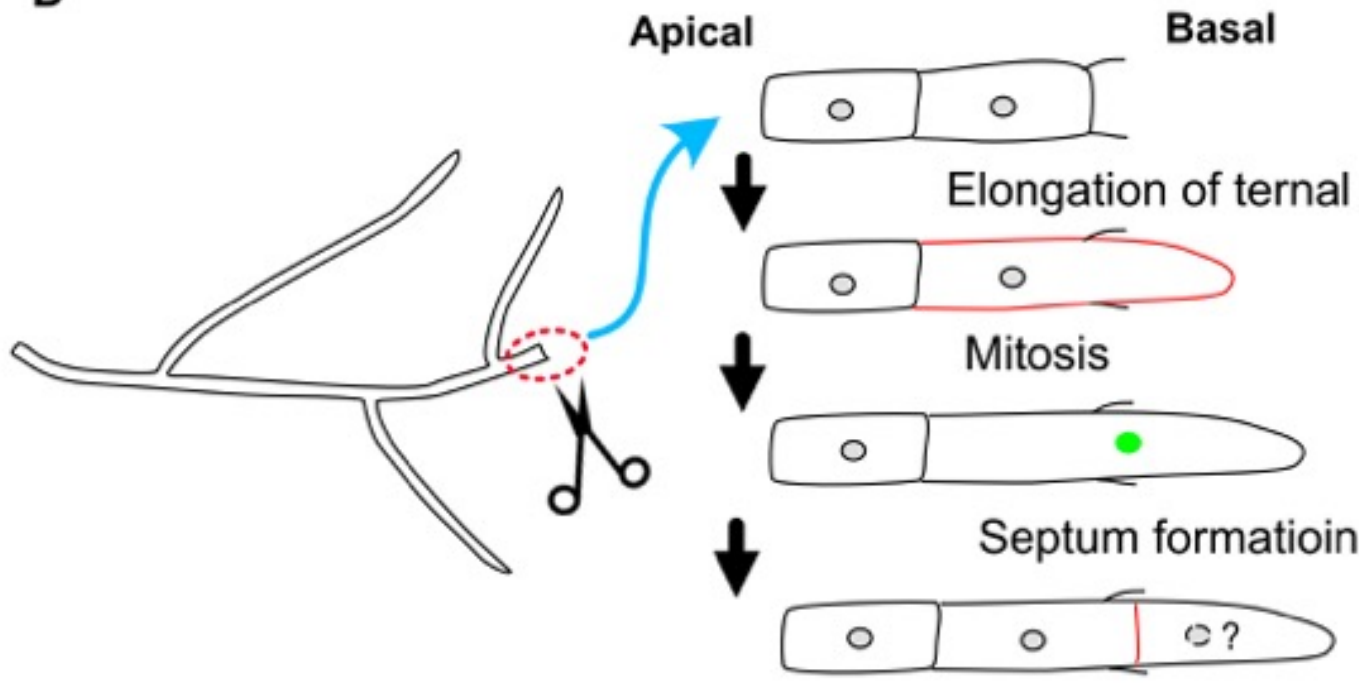

Figure 3. Tip growth, nuclear division, and septation in Colaconema sp.

(A) Colaconema sp. was isolated from the surface of Codium fragile (top). Colaconema sp. was successfully cultured in the absence of $C$. fragile in the laboratory (bottom). (B) Rhizoid formation upon severing. (C) Time-lapse imaging of the nuclei (yellow arrows) of a regenerating cell (rhizoid). The cell next to the injured cell underwent a nuclear division followed by septation (arrowhead) during tip growth. Mitotic chromosome condensation was observed at $540 \mathrm{~min}$, and sister chromatid segregation was complete by $630 \mathrm{~min}$ (a sister nucleus is out of focus). (D) Schematic presentation of the injury response in Colaconema sp. Mitotic nuclei are indicated in green. 
A

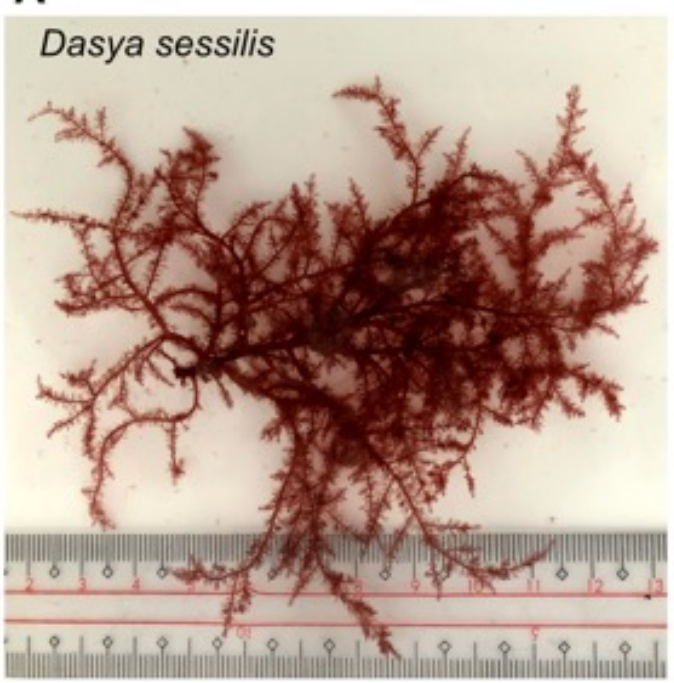

C
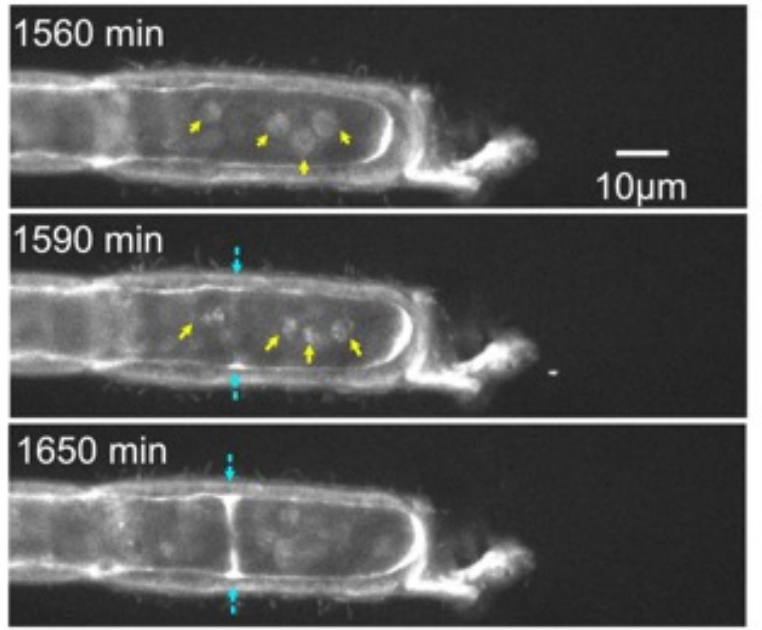

B
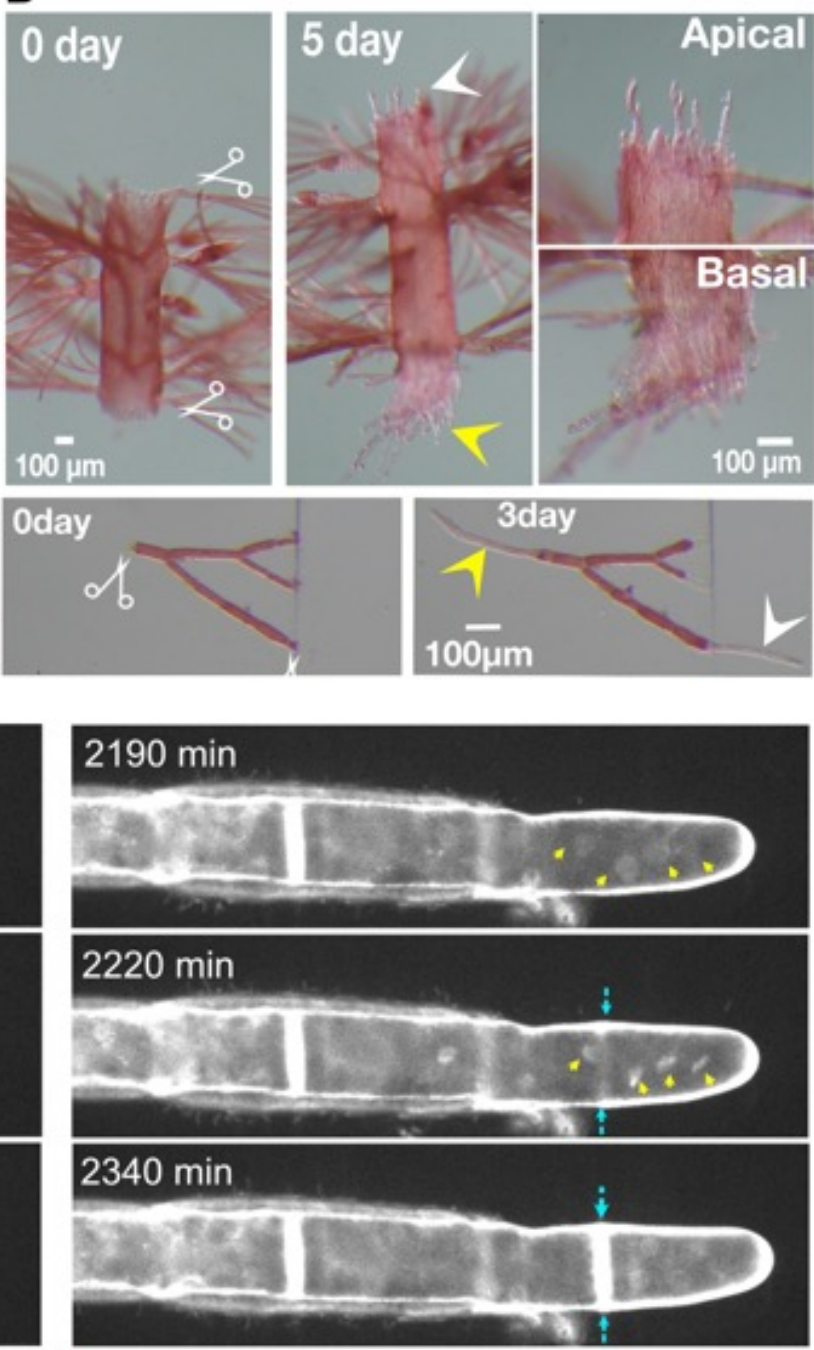

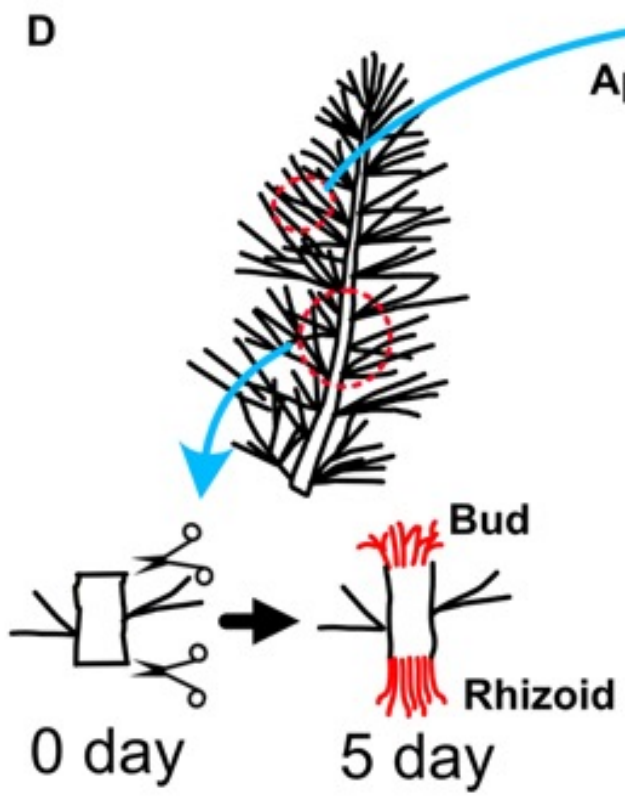

Apical

Basal
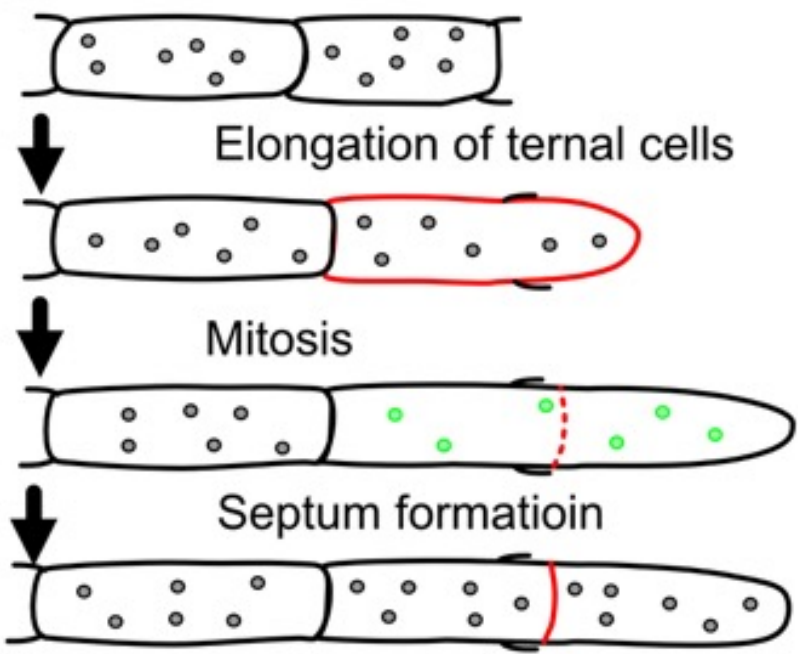

Figure 4. Tip growth, synchronised multinuclear division, and septation in Dasya sessilis. (A) Dasya sessilis. (B) Formation of buds (white arrowheads) and rhizoids (yellow arrowheads) at the apical and basal cut sites, respectively. (C) Time-lapse imaging of the nuclei of a regenerating cell (rhizoid). The cell next to the injured cell underwent two rounds of nuclear divisions and septation during tip growth. Yellow and blue arrows indicate mitotic chromosome condensation and septation, respectively. (D) Schematic presentation of the injury response in Dasya sessilis. Mitotic nuclei are indicated in green. 

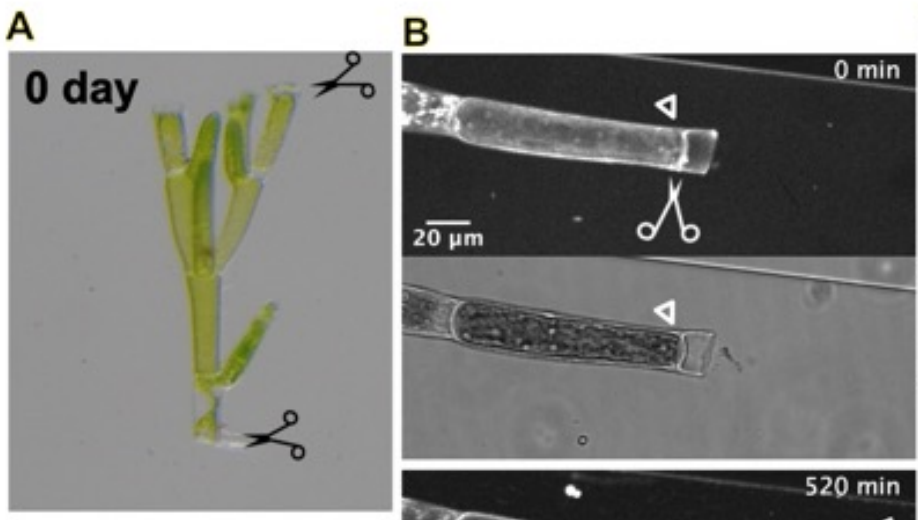

C
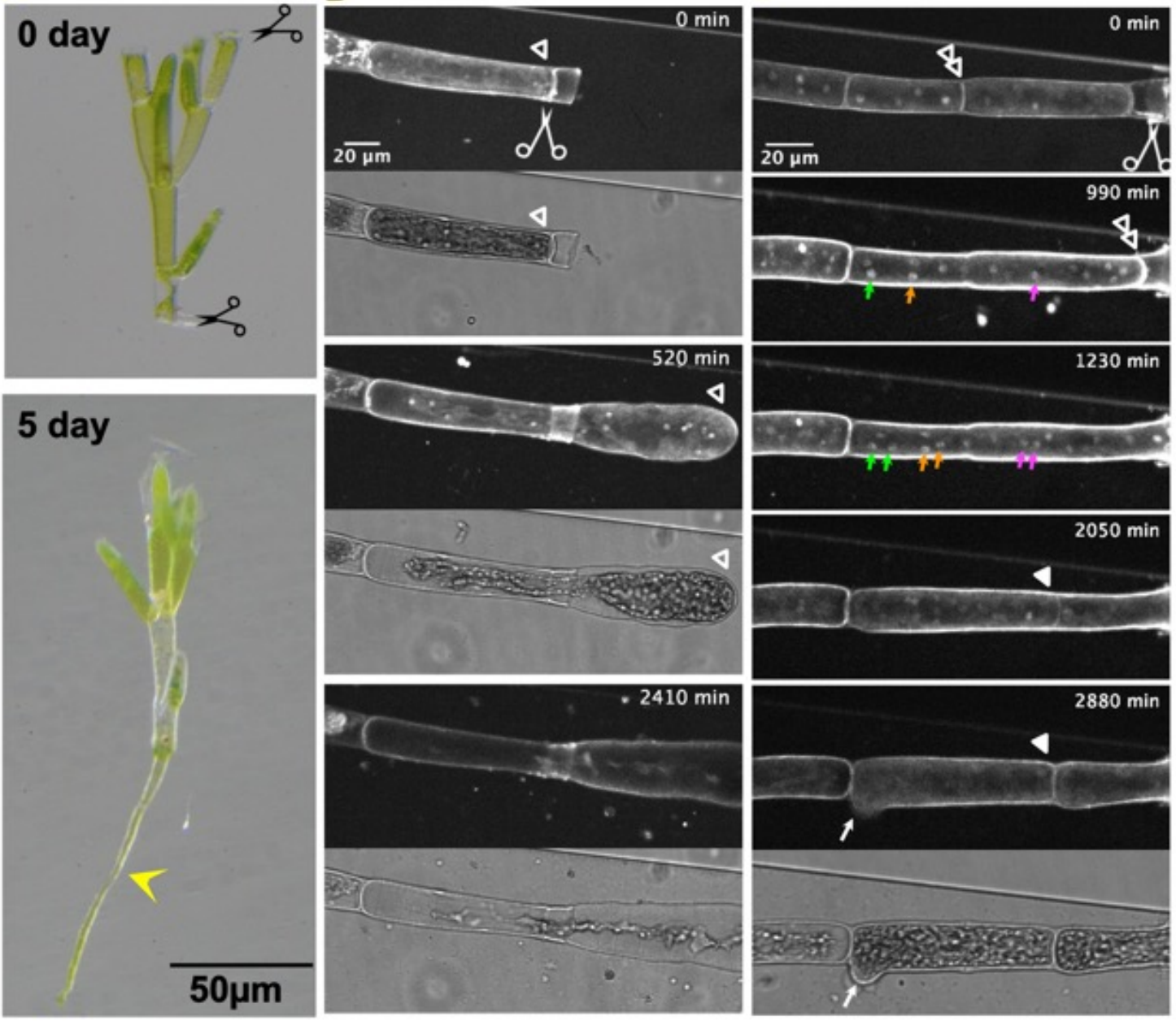

D

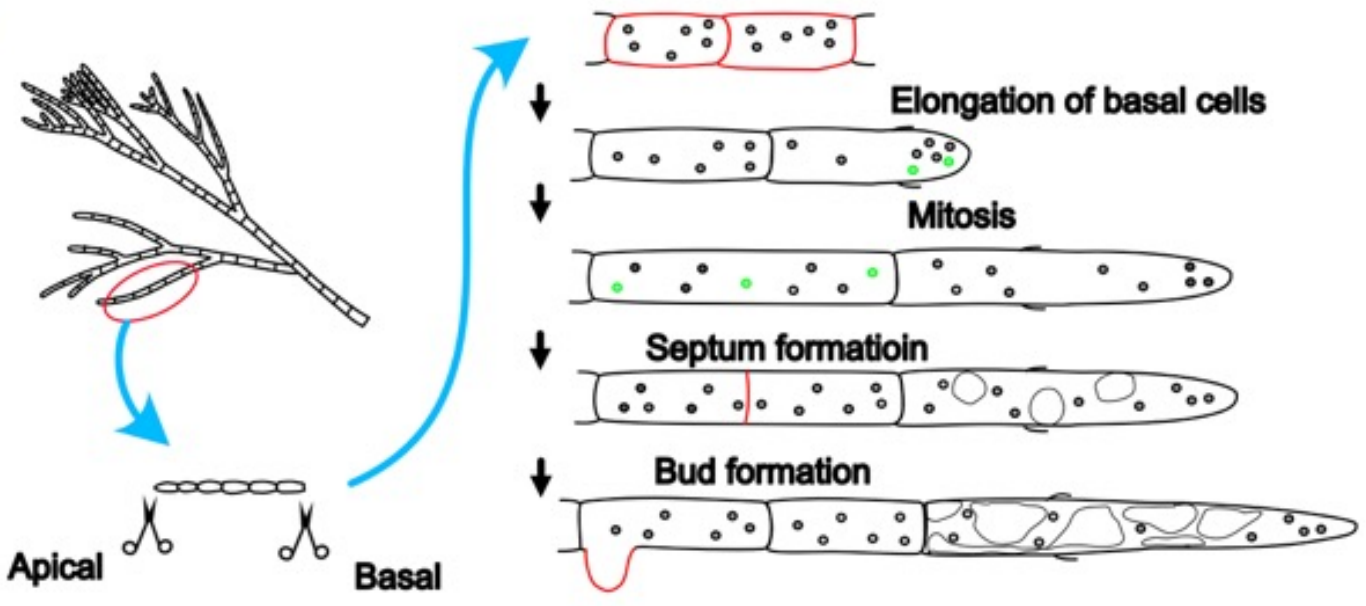

Figure 5. Tip growth, unsynchronised multinuclear division, and septation in Cladosphora albida.

(A) Formation of rhizoids (yellow arrowhead) at the basal cut site. (B, C) Time-lapse imaging of the nuclei of a regenerating cell (rhizoid). The cell next to the injured cell showed tip growth (tips are indicated by open white arrows). (B) In the majority of cases, nuclear division was undetectable, whereas the vacuole developed and occupied the cytoplasm. (C) In other cases, the growing cell underwent nuclear division, not in a synchronous manner, followed by single septation during tip growth. Branching is also observed at the end (white arrow). Green, yellow, and magenta arrows indicate mitotic chromosome condensation, whereas septation is indicated by filled white arrowheads. (D) Schematic presentation of the injury response in Cladosphora sp. Mitotic nuclei are indicated in green. 
A

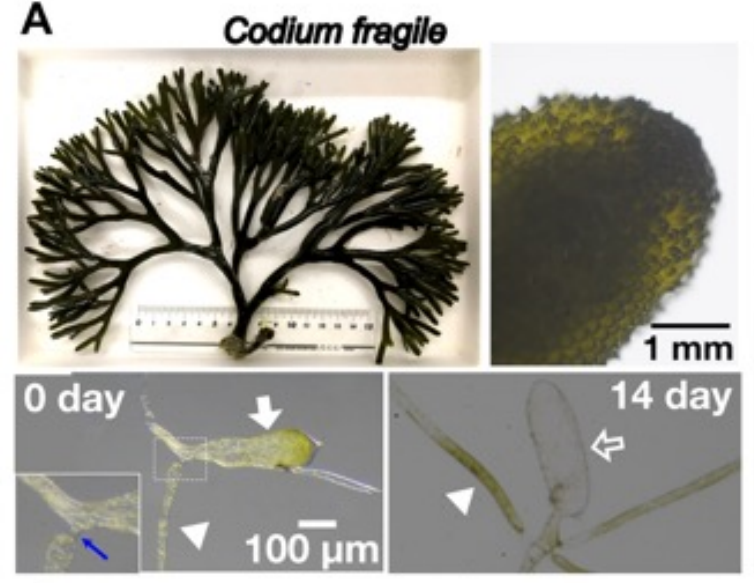

\section{C}
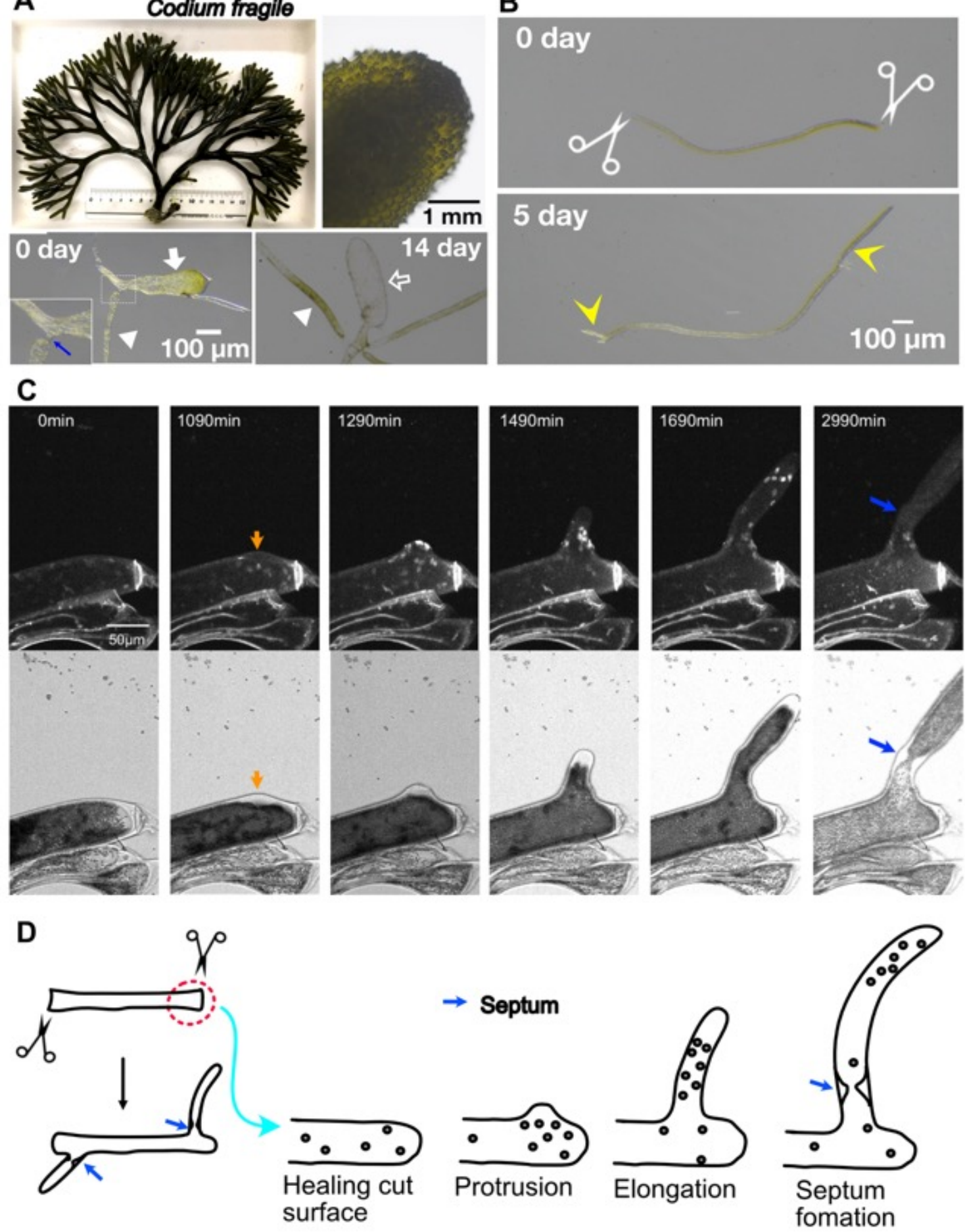

Figure 6. Cell repair, protrusion, tip growth, and nuclear migration in Codium fragile.

(A) Codium fragile. Close-up of the thalli that are composed of closely packed utricles (top right). A single utricle (bottom left, white arrow) with an incomplete septum (blue arrow) and tubular branches (white arrowhead). Fourteen days after isolation, the utricles withered (white open arrow), and the tubular branches grew to form filamentous thalli. (B) Formation of rhizoids (left arrow) and new branches (right arrow) after severing. (C) Time-lapse imaging of nuclei (dyed with Hoechst 33342) (top) and plastids that are visualized by transmission light microscopy (bottom). The cut-repaired site is located on the right (indicated by a strong, linear Hoechst signal). The orange arrow indicates the emergence of a bud. Blue arrows indicate incomplete septation. (D) Schematic presentation of the injury response of $C$. fragile. 
bioRxiv preprint doi: https:/doi.org/10.1101/2021.08.28.458046: this version posted August 29 2021. The copyright holder for this preprint (which was not certified by peer review) is the author/funder, who has granted bioRxiv a license to display the preprint in perpetuity. It is made available under aCC-BY-NC 4.0 International license.
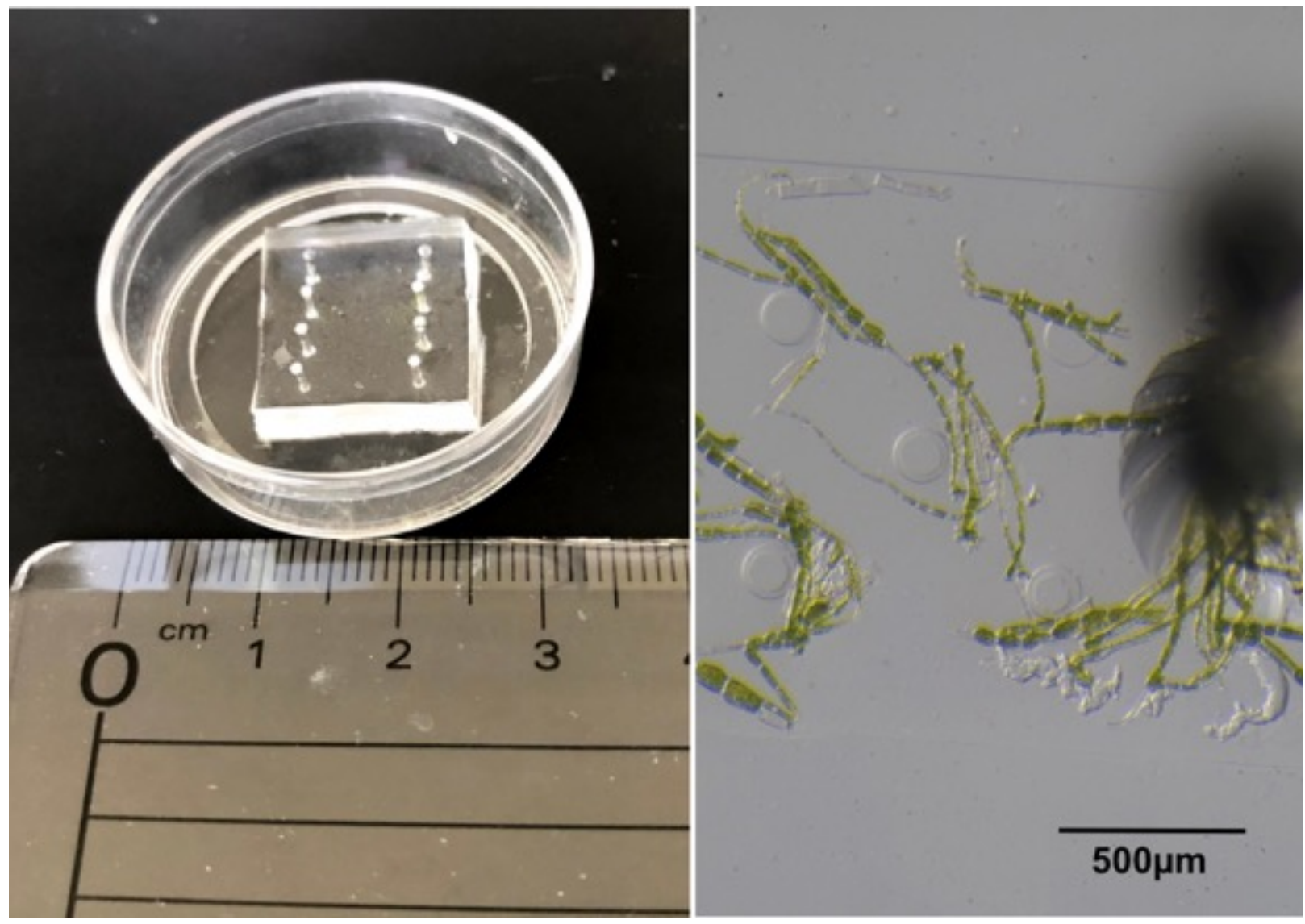

Figure S1: Microfluidic device for live-cell imaging of macroalgae.

(Left) A PDMS device, $15 \mu \mathrm{m}$ in height, was attached to the glass-bottom dish. (Right) Severed thalli of Cladosphora were injected into the device. 
A $\mathbf{0}$ day

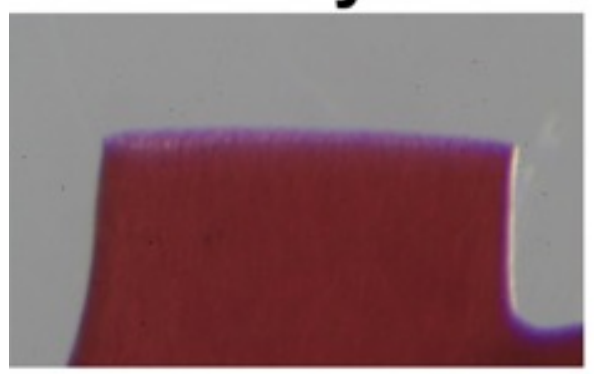

B

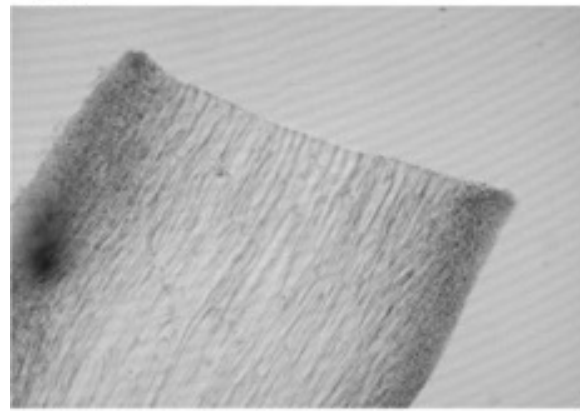

3 day
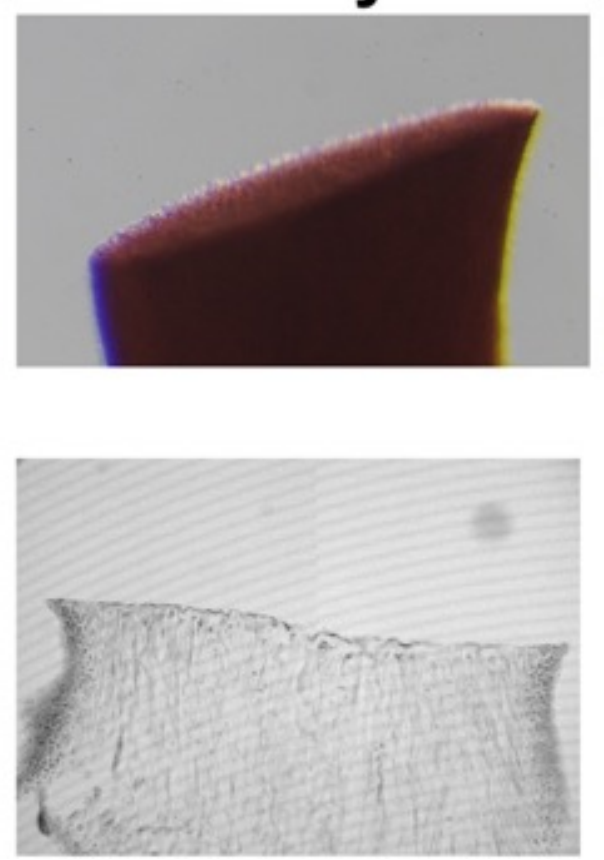

7 day
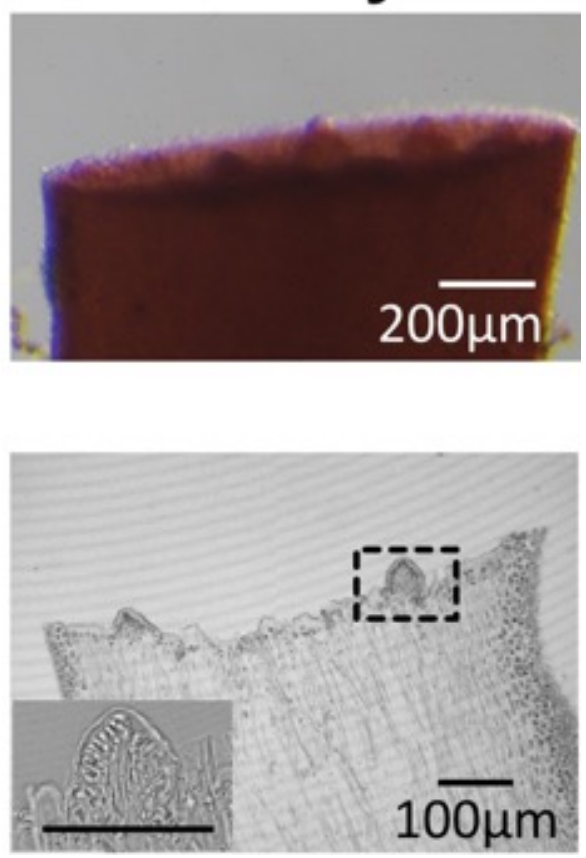

Figure S2. Budding at the severed surface in Gelidium elegans.

(A) Stereomicroscopic images of the severed surface of $G$. elegans thalli at day 0 (immediately after severing), 3, and 7. (B) Frozen section images of a cut surface of G. chorda thalli. Inset: enlarged image. 